\title{
IDENTIFICATION OF THE ENDANGERED PINK-TO-RED STYLASTER CORALS BY RAMAN SPECTROSCOPY
}

\author{
Stefanos Karampelas, Emmanuel Fritsch, Benjamin Rondeau, Aude Andouche, and Bernard Métivier
}

\begin{abstract}
All corals within the Stylasteridae family (including the Stylaster genus) are listed in Appendix II of CITES; this means they are protected and their trade requires an export permit, unlike corals from the Corallium genus, which include most pink-to-red corals used in jewelry. Raman scattering demonstrates that corals from the Stylaster genus contain carotenoid pigments (polyenic pigments substituted with methyl groups), whereas those from the Corallium genus are colored by unmethylated polyenic pigments. Additionally, Stylaster corals are made of aragonite, whereas those from Corallium are composed of calcite. Through Raman scattering analysis, the fully protected Stylaster pink-to-red corals may be distinguished from this other type of gem coral.
\end{abstract}

n June 2007, delegates from 171 countries convened at The Hague to decide which species to include under the CITES (Convention on International Trade in Endangered Species of Wild Fauna and Flora) agreement. The aim of CITES is to ensure that international trade in plant and animal specimens does not threaten their survival. The species covered by the convention are listed in three appendices, according to the degree of protection they need. Appendix I includes species threatened with extinction, where trade is permitted only in exceptional circumstances. Species in Appendix II are not necessarily threatened with extinction, but their trade must be controlled to avoid use that would threaten their survival. Appendix III contains species that are protected in at least one country that has asked other CITES parties for assistance in controlling the trade.

The gemological significance of this triennial meeting is that corals from the Corallium genus, the most impor-

See end of article for About the Authors and Acknowledgments.

Gems \& Gemology, Vol. 45, No. 1, pp. 48-52.

(C) 2009 Gemological Institute of America tant of all gem coral species, were being considered for protection under Appendix II (CITES, 2008a). Ultimately, it was decided not to include them. More recently, on April 8, 2008, China, which now has domestic laws to protect these species, requested that CITES include four Corallium species (C. elatius, C. japonicum, C. konjoi, and C. secundum) under Appendix III (Fish and Wildlife Service, 2008). Meanwhile, the Stylasteridae family, which includes all Stylaster gem corals (e.g., figure 1), remained listed under Appendix II of CITES (as of January 18, 1990), which means a certificate issued by the management authority from the country (or state) of export is required (CITES, 2008b).

Pink-to-red corals have been used for ornamental purposes for about 10,000 years (Liverino, 1989). According to Rolandi et al. (2005), there are two classes, Hydrozoa and Anthozoa, within the Cnidaria phylum (i.e., cnidarians) that have skeletons durable enough for use in gem materials and carvings. These two classes each contain a family (Stylasteridae and Coralliidae, respectively) that together yield the majority of pink-to-red coral species used for ornamentation (Pienaar, 1981; Rolandi et al., 2005; Smith et al., 2007). Most corals found in the

Figure 1. These orangy pink cabochons $(12 \times 12 \times 5 \mathrm{~mm})$ were fashioned from Stylaster coral. No evidence of dye or impregnation was detected in these specimens. Photo by B. Rondeau.

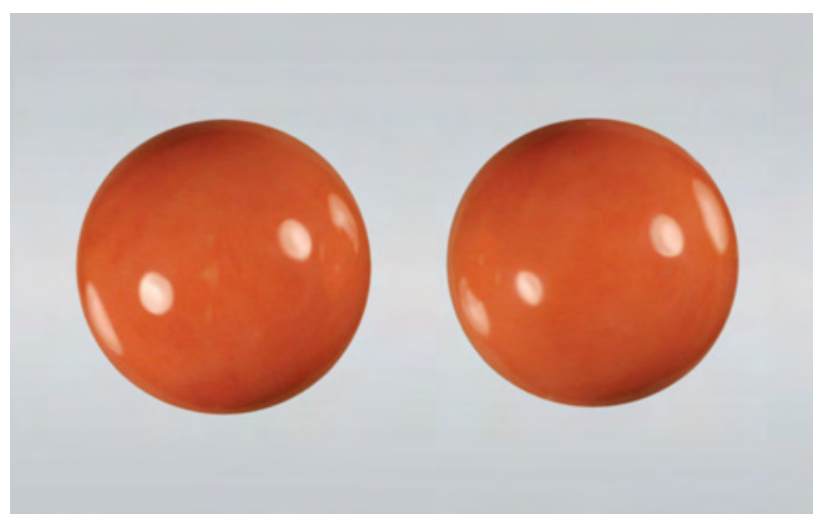




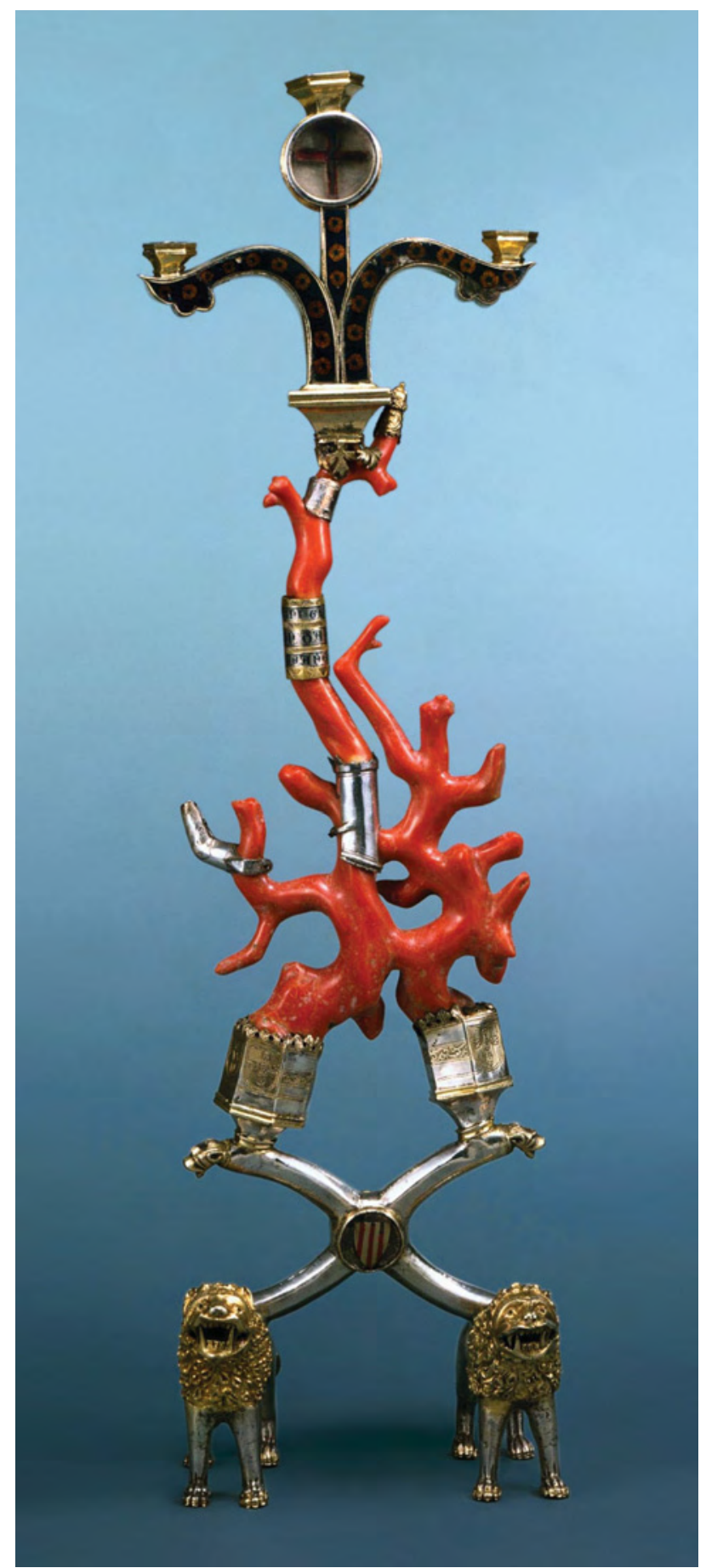

Figure 2. This early 15 th century Portuguese reliquary holding a fragment of the Holy Cross features red Corallium coral. The piece measures $53.2 \mathrm{~cm}$ tall and $20.0 \mathrm{~cm}$ wide. Courtesy of Museu Nacional de Machado de Castro, Coimbra, Portugal; collection no. MNMC 6036, @ DDF/IMC.

market today are from the Corallium genus, including the prized "ox-blood" (dark red; figure 2) and "angelskin" (light pink; figure 3) colors.
Corals from the Corallium genus are found in waters throughout the world-notably the Mediterranean Sea and the Atlantic, Pacific, and Indian Oceans-as are corals from the Stylaster genus (e.g., Pienaar, 1981; Rolandi, 1981; Rolandi et al., 2005; Smith et al., 2007; CITES, 2008a). Stylaster corals (sometimes referred to as "lace" corals; figure 4) are typically impregnated and/or dyed and may be used as a substitute for Coralliummostly as beads and cabs. In such forms, it is sometimes difficult to precisely identify any coral by routine gemological examination. Stylaster corals are also found with natural purple and violet coloration (e.g., S. californicus and S. subviolaceus).

Careful observation of the structural features found in the Stylaster and Corallium genera may be useful in identifying the particular species of a coral jewel. Stylaster corals typically contain surface pores (again, see figure 4) that are arranged in circular patterns called cyclo-systems (Pienaar, 1981; Rolandi, 1981; Rolandi et al., 2005). Corals from the Corallium genus typically have striated or scalloped structures (Smith et al., 2007).

The specific gravity of coral ranges from 2.37 to 2.75 , and it is strongly dependent on the porosity of the individual piece. The refractive indices of both calcitic and aragonitic corals are a function of their calcium carbonate configuration. RI is also influenced by the magnesium content of calcitic corals and the strontium content of aragonitic corals (Rolandi et al., 2005). Because corals from these two genera can be difficult to separate using only classical

Figure 3. The pink Corallium coral in this 6-cm-tall clip is set with emerald, amethyst, and diamond. Courtesy of Van Cleef $\Theta$ Arpels.

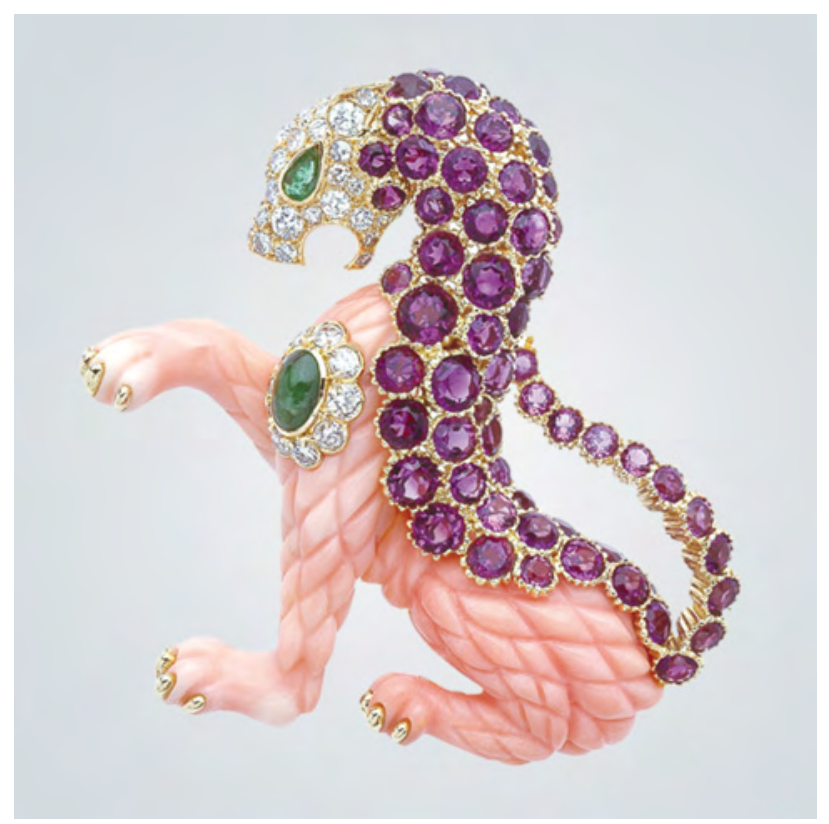




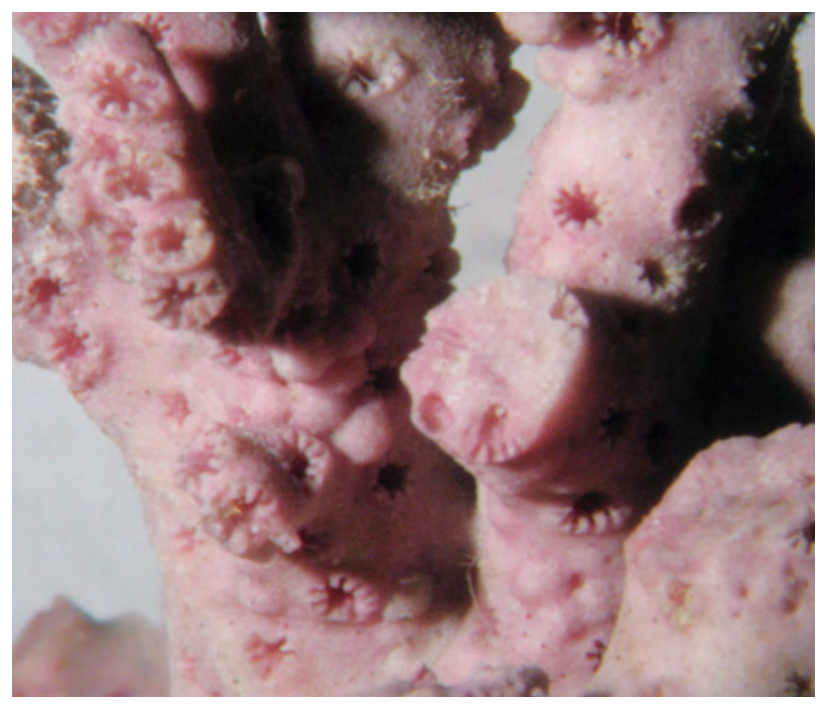

Figure 4. Corals of the Stylasteridae family, such as this pink specimen of the species Stylaster roseus (sample no. 1; other portions of this same specimen were red) are protected by CITES. Note the distinctive surface pores of this "lace" coral. Courtesy of MNHN, Paris (Collection no. MNHN-Hyd.00000001); photo by S. Karampelas, image width $9 \mathrm{~cm}$.

gemological methods, the present study explores their identification based on Raman scattering analysis.

Materials and Methods. This study was carried out on seven pink-to-red coral specimens from the collections of the Muséum National d'Histoire Naturelle (MNHN; National Museum of Natural History) in Paris and the Centre de Recherche Gemmologique (CRG; Center for Gemmological Research) in Nantes. Two of the samples (nos. 1 and 2) belong to the Stylaster genus, and the other five (nos. 3-7) to the Corallium genus. See table 1 for their detailed taxonomy, color description, and geographic origin. All seven specimens were represented as being of natural color, and this was verified by standard gemological examination (i.e., microscopic observation and fluorescence to UV radiation). Note that we could not obtain a group photo of the samples because we did not have access to all of them at the same time.

We recorded Raman scattering spectra with a Jobin Yvon T64000 spectrometer coupled with an Olympus microscope at the University of Nantes. The study used an excitation laser emitting at $514 \mathrm{~nm}$ (argon ion laser), with a power of $2 \mathrm{~mW}$ and a resolution of $1 \mathrm{~cm}^{-1}$ at room temperature. A low-power laser was selected to avoid destroying the corals' fragile organic matter. For samples with varying color distribution, spectra were taken in different-colored areas as identified by the spectrometer's microscope (50× magnification). The analyzed areas measured about $2 \times 2 \mu \mathrm{m}$. Measurements were repeated at least twice in the same area to ensure reproducibility. Exposure time was 240 seconds.

Results and Discussion. Raman spectra of two light pink corals of different species, Corallium secundum and Stylaster sanguineus, in the $1600-600 \mathrm{~cm}^{-1}$ range are presented in figure 5 . In the $C$. secundum spectrum, two bands at $\sim 1088$ and $714 \mathrm{~cm}^{-1}$ correspond to the $v_{1}$ symmetric and $v_{4}$ in-plane bending of carbonate ions $\left(\mathrm{CO}_{3}^{2-}\right)$ in calcite, respectively (Urmos et al., 1991). The two bands at $\sim 1520$ and $1130 \mathrm{~cm}^{-1}$ are characteristic of unmethylated polyenic pigments; they are assigned, respectively, to C-C $\left(v_{1}\right)$ and $\mathrm{C}=\mathrm{C}\left(v_{2}\right)$ stretching (Merlin and Delé-Dubois, 1986; Karampelas et al., 2007).

Polyenes (or polyacetylenes, cited here as unmethylated polyenes) are organic compounds that contain several sequences of alternating double and single carbon-carbon bonds (i.e., a polyenic chain). Polyenic molecules can have

TABLE 1. Taxonomy ${ }^{\mathrm{a}}$, color range, and geographic origin of the seven coral samples.

\begin{tabular}{|c|c|c|c|c|c|c|c|}
\hline $\begin{array}{l}\text { Sample } \\
\text { no. }\end{array}$ & Class & Order & Family & $\begin{array}{l}\text { Genus } \\
\text { and species }\end{array}$ & Color range & $\begin{array}{l}\text { Geographic } \\
\text { origin }\end{array}$ & Collection ${ }^{b}$ \\
\hline 1 & Hydrozoa & Anthoathecatae & Stylasteridae & Stylaster roseus & Light pink to red & Unknown & MNHN \\
\hline 2 & Hydrozoa & Anthoathecatae & Stylasteridae & Stylaster sanguineus & Light to dark pink & $\begin{array}{l}\text { Pacific Ocean } \\
\text { (Hawailan Islands) }\end{array}$ & MNHN \\
\hline 3 & Anthozoa & Alcyonacea & Coralliidae & Corallium rubrum & Light to dark red & $\begin{array}{l}\text { Mediterranean Sea } \\
\text { (southern France) }\end{array}$ & CRG \\
\hline 4 & Anthozoa & Alcyonacea & Coralliidae & Corallium rubrum & Light to dark red & $\begin{array}{l}\text { Mediterranean Sea } \\
\text { (southern France) }\end{array}$ & $\mathrm{CRG}$ \\
\hline 5 & Anthozoa & Alcyonacea & Coralliidae & Corallium rubrum & Light to dark pink & Unknown & MNHN \\
\hline 6 & Anthozoa & Alcyonacea & Coralliidae & Corallium rubrum & $\begin{array}{l}\text { Light to dark red } \\
\text { to orange }\end{array}$ & $\begin{array}{l}\text { Atlantic Ocean } \\
\text { (Republic of Senegal) }\end{array}$ & MNHN \\
\hline 7 & Anthozoa & Alcyonacea & Coralliidae & Corallium secundum & Light to dark pink & $\begin{array}{l}\text { Pacific Ocean } \\
\text { (Hawaiian Islands) }\end{array}$ & MNHN \\
\hline
\end{tabular}

${ }^{a}$ Taxonomy follows the Integrated Taxonomic Information System, www.itis. gov (Phylum: Cnidaria).

${ }^{b}$ MNHN = Muséum National d'Histoire Naturelle (Paris); CRG = Centre de Recherche Gemmologique (Nantes, France). 
various substitutions at their terminations. The general chemical formula of these compounds is R-(-CH=CH- $)_{n}-\mathrm{R}^{\prime}$ (where $n=$ number of double bonds, and $\mathrm{R}$ and $\mathrm{R}^{\prime}=$ end groups; Merlin and Delé-Dubois, 1986; Karampelas et al., 2007). We obtained similar results for different areas in all the samples within the Corallium genus $\left(v_{1}: 1130 \pm 5 \mathrm{~cm}^{-1}\right.$; $v_{2}: 1520 \pm 10 \mathrm{~cm}^{-1}$. Raman peaks at the same positions have been documented in the spectra of other Corallium species (see Merlin and Delé-Dubois, 1986; Urmos et al., 1991; Kaczorowska et al., 2003; Rolandi et al., 2005; Smith et al., 2007; and Fan and Yang, 2008).

In the spectrum of $S$. sanguineus, we observed a band at about $1085 \mathrm{~cm}^{-1}$ and a doublet at 706 and $702 \mathrm{~cm}^{-1}$ (see inset to figure 5); the band and doublet correspond to the $v_{1}$ symmetric and $v_{4}$ in-plane bending of $\mathrm{CO}_{3}^{2-}$ ions in aragonite, respectively (Urmos et al., 1991). Two additional peaks at $\sim 1511$ and $1155 \mathrm{~cm}^{-1}$ are characteristic of carotenoid pigments (Merlin and Delé-Dubois, 1986). Carotenoid pigments are also polyenic molecules, with various substitutions on their terminal ends and an additional

Figure 5. In the Raman spectrum of Corallium secundum (red line; sample no. 7), bands due to calcite are observed at $1088 \mathrm{~cm}^{-1}$ and $714 \mathrm{~cm}^{-1}$. The two bands at 1520 and $1130 \mathrm{~cm}^{-1}$ are due to unmethylated polyenic pigments. In the spectrum of Stylaster sanguineus (orange line; sample no. 2), aragonite bands are observed at 1085, 706, and $702 \mathrm{~cm}^{-1}$ (see inset). Two sharp bands at 1511 and $1155 \mathrm{~cm}^{-1}$ are due to carotenoids. Among corals of gemological interest, only the Stylaster genus appears to contain aragonite and carotenoid pigments. Note that the spectra are normalized to the major Raman peak of carbonate $\left(\sim 1088 \mathrm{~cm}^{-1}\right.$ for calcite and $1085 \mathrm{~cm}^{-1}$ for aragonite). The spectra have been stacked and shifted vertically for clarity.

\section{RAMAN SPECTRA}

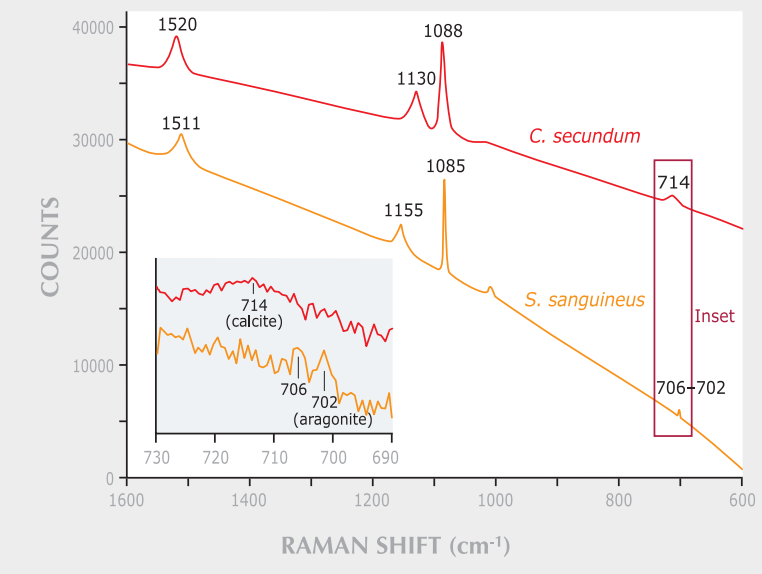

four methyl groups attached to their polyenic chain. In carotenoids, the $v_{1}$ vibration is modified by the presence of additional methyl $\left(\mathrm{CH}_{3}\right)$ groups in the polyenic chain (methyl in-plane bending modes); hence, the Raman peak is shifted $25( \pm 10) \mathrm{cm}^{-1}$ (Okamoto et al., 1984). This difference (1130 vs. $1155 \mathrm{~cm}^{-1}$ in figure 5) is substantial enough to separate unmethylated polyenes (corals of the Corallium genus) from carotenoids (corals from Stylaster) unambiguously.

The position of the other peak related to polyenic chains, at $1520 \pm 10 \mathrm{~cm}^{-1}$ (under $514 \mathrm{~nm}$ excitation), is dependent on the number of carbon double bonds in the chain. Thus, for a given number of double bonds, this particular Raman peak is in the same position for a carotenoid and an unmethylated polyenic molecule (Okamoto et al., 1984). In different areas of the two Stylaster corals, we obtained similar results for each of the two peaks (1155 \pm 5 $\mathrm{cm}^{-1}$ and $1520 \pm 10 \mathrm{~cm}^{-1}$ ). Rolandi et al. (2005), again, measured peaks at the same positions for other species within the Stylaster (stated as "Allopora") genus. Destructive studies on extracted pigments from Stylaster corals also demonstrated that they contain carotenoids (Ronneberg et al., 1979).

Moreover, a recent study has shown that the different colors seen in some corals are actually due to mixtures of several types of carotenoids (e.g., orange Stylaster) or unmethylated polyenes (e.g., pink Corallium; Karampelas et al., 2007). Thus, the natural colors of pink-to-red Stylaster and Corallium corals result from the nature and relative proportions of several carotenoids and unmethylated polyenes, respectively.

Conclusion. Gem corals from the Stylaster genus are protected by Appendix II of CITES, and a certificate issued by the management authority of the country (or state) of export is required for any new material released (import/export of a Stylaster coral from old stock is permitted; for more information about the legal framework of importing/exporting species protected by Appendix II, consult CITES, 2008c). Currently, there are no such restrictions on corals of the Corallium genus.

This study showed that pink-to-red Stylaster corals contain carotenoid pigments and are aragonitic, while those from the Corallium genus contain unmethylated polyenic pigments and are calcitic, so they can be separated on this basis using Raman spectroscopy. A review of the literature indicates that Stylaster is the only pinkto-red gem coral that contains carotenoid pigments. Thus, if a coral from the Stylaster genus cannot be distinguished by its surface features, it can be identified nondestructively using Raman scattering. Raman spectra of additional natural-color coral specimens from these and other genera need to be collected to refine this criterion. Raman spectroscopy may also prove useful to gemologists in detecting other materials protected by CITES, such as ivory and pearls. 


\section{ABOUT THE AUTHORS}

At the time this article was prepared, Dr. Karampelas (s.karampelas@gubelingemlab.ch) was a Ph.D. student in the Department of Mineralogy-Petrology-Economic Geology at Aristotle University of Thessaloniki in Greece and at the Institut des Matériaux Jean Rouxel at the University of Nantes (IMNCNRS), France. He is now a postdoctoral researcher at the Gübelin Gem Lab in Lucerne, Switzerland. Dr. Fritsch is professor of physics at IMN-CNRS. Dr. Rondeau is assistant professor at the University of Nantes. Mrs. Andouche is curator of the Cnidaria collection, and Dr. Métivier is assistant professor, at the Muséum National d'Histoire Naturelle in Paris.

\section{ACKNOWLEDGMENTS}

The authors thank the Muséum National d'Histoire Naturelle in Paris, which loaned five of the samples for this study. Rui Galopim de Carvalho (Sintra, Portugal) and Pedro Miguel Ferrão (Museu Nacional de Machado de Castro, Coimbra, Portugal) kindly arranged for the photo in figure 2, and Dominique Dufermont Nan Cleef \& Arpels, Paris) generously provided the photo in figure 3.

\section{REFERENCES}

Convention on International Trade in Endangered Species (2008a) Consideration of proposals of amendment of Appendices I and II. www.cites.org/eng/cop/14/prop/E14-P21.pdf [date accessed: Oct. 25, 2008].

Convention on International Trade in Endangered Species (2008b) Appendices I, II and III. www.cites.org/eng/app/appendices.shtml [date accessed: Oct. 25, 2008].

Convention on International Trade in Endangered Species (2008c) Article IV: Regulation of trade in specimens of species included in Appendix II. www.cites.org/eng/disc/text.shtml\#IV [date accessed: Oct. 25, 2008].

Fan L., Yang M. (2008) In situ resonance Raman spectra of organic pigments in Momo coral. Journal of China University of Geosciences, Vol. 19, No. 2, pp. 146-151.
Fish and Wildlife Service (2008) New CITES Appendix-III listing by China for four species of Corallium coral. www.fws.gov/le/ PubBulletins/PB040808CITESAppendixIIIListingChina.pdf [date accessed: Sept. 30, 2008].

Kaczorowska B., Hacura A., Kupka T., Wrzalik R., Talik E., Pasterny G., Matuszewska A. (2003) Spectroscopic characterization of natural corals. Analytical and Bioanalytical Chemistry, Vol. 377, No. 6, pp. 1032-1037.

Karampelas S., Fritsch E., Sklavounos S., Soldatos T. (2007) Polyacetylenic pigments found in pearls and corals. Proceedings of the 30th International Gemmological Conference, Institute of Problems of Chemical Physics, Russian Academy of Sciences, Moscow, pp. 49-51.

Liverino B. (1989) Red Coral, Jewel of the Sea. Transl. by J. H. Johnson, Analisi Editions, Bologna, Italy, 208 pp.

Merlin J.C., Delé-Dubois M.L. (1986) Resonance Raman characterization of polyacetylenic pigments in the calcareous skeleton. Comparative Biochemistry and Physiology Part B: Biochemistry and Molecular Biology, Vol. 84B, No. 1, pp. 97-103.

Okamoto H., Saito S., Hamaguchi H., Tasumi M., Eugster C. (1984) Resonance Raman spectra and excitation profiles of tetradesmethyl- $\beta$-carotene. Journal of Raman Spectroscopy, Vol. 15, No. 5, pp. 331-335.

Pienaar H.S. (1981) African star coral, a new precious stylasterine coral from the Aghulas bank, South Africa. Journal of Gemmology, Vol. 17, No. 8, pp. 589-601.

Rolandi V. (1981) Les gemmes du régne animal: étude gemmologique des sécrétions des Cnidaires. Revue de Gemmologie a.f.g., Vol. 66, No. 1, pp. 3-9.

Rolandi V., Brajkovic A., Adamo I., Bocchio R., Landonio M. (2005) Gem corals: Classification and spectroscopic features. Australian Gemmologist, Vol. 22, No. 7, pp. 285-297.

Ronneberg H., Fox D., Liaaen-Jensen S. (1979) Animal carotenoidscarotenoproteins from hydrocorals. Comparative Biochemistry and Physiology Part B: Biochemistry and Molecular Biology, Vol. 64B, No. 4, pp. 407-408.

Smith C.P., McClure S., Eaton-Magaña S., Kondo D. (2007) Pinkto-red coral: A guide to determining origin of color. $G \uplus G$, Vol. 43, No. 1, pp. 4-15.

Urmos J., Sharma S.K., Mackenzie F.T. (1991) Characterization of some biogenic carbonates with Raman spectroscopy. American Mineralogist, Vol. 76, No. 3-4, pp. 641-647.

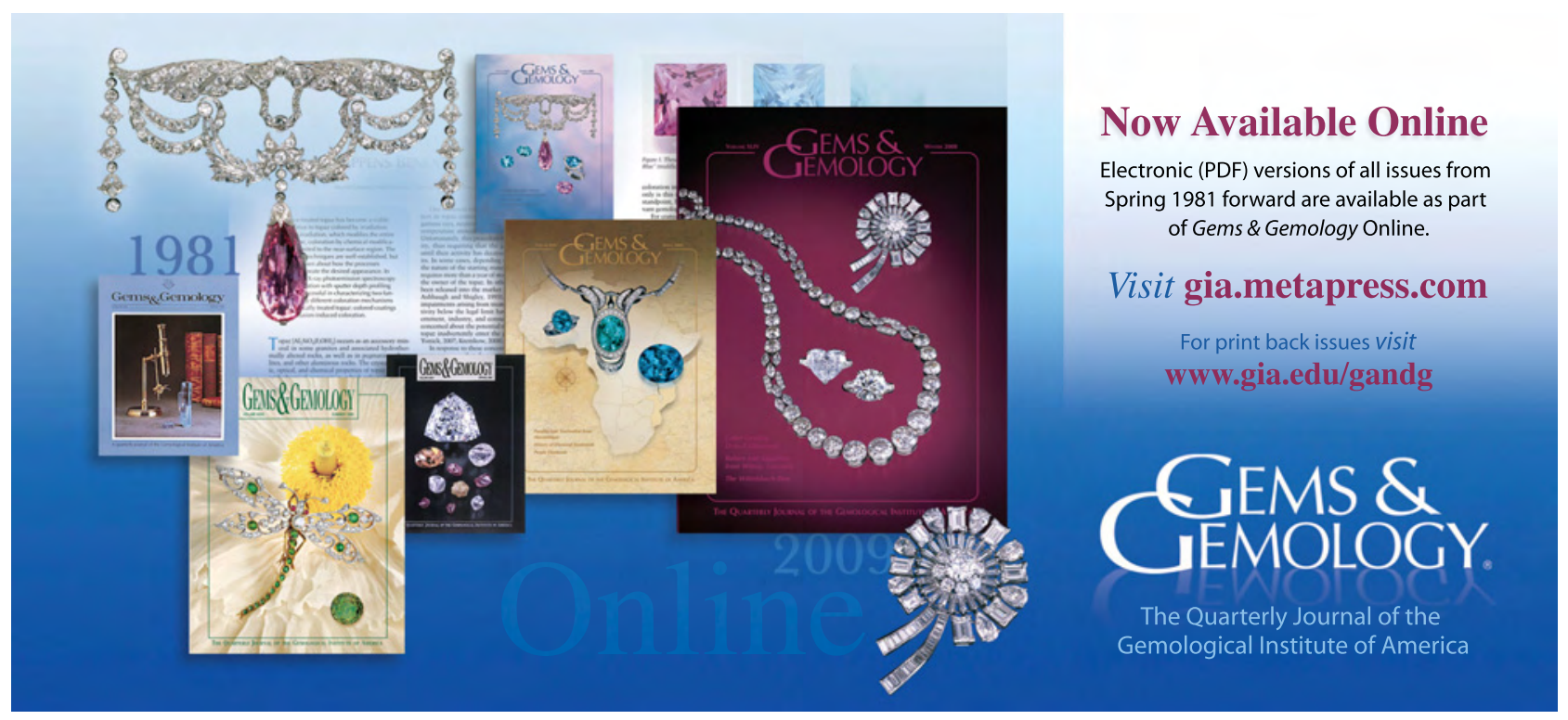

